Original Articles

\title{
The influence of breastfeeding duration and introduction of animal source foods, fruit juice and vegetables on the risk of weight gain in Thai children
}

\author{
Seo Ah Hong ${ }^{1,2}$, *Aroonsri Mongkolchati ${ }^{1}$, Taksin Pimpak ${ }^{3}$
}

Sri Lanka Journal of Child Health, 2017; 46(2): 108-116

\begin{abstract}
Objective: To examine the influence of infant feeding practices on weight gain in children at 24 months of age.
\end{abstract}

Method: Study data were from 4,245 children from the prospective cohort study of Thai children conducted in 2000-2002. Information on breast feeding duration and timing of specific types of complementary foods introduction was collected in infancy. Overweight (BMI-for-age $>2$ SD from WHO standard median) and weight gain (weight at birth minus body weight at 24 months) were evaluated.

Results: Breastfeeding for 12 months or more reduced the weight gain $(\beta=-0.0101, \mathrm{p}<0.0001)$ and the risk of overweight $(\mathrm{aOR}=0.24,95 \% \mathrm{CI}=0.15$ 0.40 ) after adjustment for confounders. In light of specific types of foods, overweight risk decreased with increasing age at introduction of animal source foods $(\mathrm{aOR}=0.78,95 \% \mathrm{CI}=0.67-0.91)$, vegetables $(\mathrm{aOR}=0.85,95 \% \mathrm{CI}=0.76-0.96)$, and fruit juices $(\mathrm{aOR}=0.92,95 \% \mathrm{CI}=0.83-1.01)$, whereas weight gain had an inverse association with animal source foods $(p=0.0004)$ and vegetables $(p<0.0001)$.

${ }_{1}^{1}$ ASEAN Institute for Health Development, Mahidol University, Thailand, ${ }^{2}$ Institute for Health and Society, Hanyang University, Seoul, Republic of Korea, ${ }^{3}$ College of Medicine and Public Health, Ubon Ratchathani University, Thailand

*Correspondence: aroonsri.mon@mahidol.edu

(Received on 29 May 2016: Accepted after revision on 15 July 2016)

The authors declare that there are no conflicts of interest

The study was supported by Thailand Research Fund, Health System Research Institute, Ministry of Public Health, DUMEX Science, ASEAN Institute for Health Development, Mahidol University, and World Health Organization.

Open Access Article published under the Creative

Commons Attribution CC-BY (Cc)
Conclusion: This study concluded that longer duration of breastfeeding and late introduction of animal source foods, fruit juices and vegetables decreased weight gain or overweight risk in children at 24 months of age.

DOI: http://dx.doi.org/10.4038/sljch.v46i2.8264

(Keywords: Breastfeeding duration, complementary food introduction, weight gain, obesity)

\section{Introduction}

Obesity starts early and tends to persist into childhood and adulthood ${ }^{1}$. Research has therefore focused on identifying the factors attributable to the development of obesity with emphasis on the first year of life as a critical period to target ${ }^{2}$. Appropriate feeding practices during infancy are essential for the development of children ${ }^{3}$. There are many studies on the effects of proper infant feeding on the child development. Nevertheless, effects of breastfeeding (BF) and timing of complementary food (CF) introduction on the development of obesity are not conclusive even today. Furthermore, the effect in low- and middle-income countries is questionable, because most studies were evaluated in high income countries $^{4-6}$. In addition, infant feeding practice, such as types of CF when stopping BF between high- and low-income countries is different. Therefore, studies on the effect of infant feeding practice, such as $\mathrm{BF}$ and timing of $\mathrm{CF}$ introduction in low- and middle-income countries were suggested ${ }^{7}$. But only one Danish study has evaluated the effect of timing of complementary food introduction, particularly in terms of specific types of foods.

Thailand has recently experienced significant economic growth, and as a result, prevalence of obesity and obesity-related diseases has been increasing at an alarming rate ${ }^{8}$. The prevalence of obesity defined with BMI 25 or more in Thai adults almost doubled from $18.2 \%$ in $1991^{1,9}$ to $34 \%$ in 2008- $9^{8}$. Among under five children, the overweight also sharply increased from $6.9 \%$ in $2006^{10}$ to $11 \%$ in $2012^{2,11}$. The dramatic increase led to increment in health care usage resulting from obesity-related diseases, which has had a significant economic impact on the health care system in Thailand. The 
total cost of obesity was estimated at 12,142 million Baht, accounting for $0.13 \%$ of Thailand's Gross Domestic Product (GDP) ${ }^{8}$. These make it clear that Thailand is facing an obesity epidemic that can no longer be ignored. This entails a need to identify early determinants of overweight for prompt intervention to prevent obesity in early year settings. Therefore, we aimed to evaluate the association of duration of any $\mathrm{BF}$ and timing of $\mathrm{CF}$ introduced with weight gain and the risk of overweight in 2 year-old children. We used data from the Prospective Cohort study of Thai Children (PCTC) in Thailand. Findings from this study have significant implications for other developing countries in transition $^{12}$.

\section{Objective}

To examine the influence of infant feeding practices on weight gain in children at 24 months of age.

\section{Method}

Study dataset and subjects

A total of 4,245 24-month-old children from the prospective cohort study of Thai children (PCTC), based on 5 regions reflecting socioeconomic and cultural characteristics (Panomtuan District in Kanchanaburi, Thepa District in Songkla, Kranuan District in Konkaen, Muang District in Nan, and Bangkok) were recruited from October 2000 to September 2002. Study methods have been described in detail elsewhere ${ }^{3,13}$. Infants born as twins $(\mathrm{N}=60)$ or who died before 24 months due to significant health problems, such as birth defects, deficits of physical development $(\mathrm{N}=34)$ or born from teenage mothers $(\mathrm{N}=487)$, who tended to deliver abnormally and have babies with low birth weight and lower education level than adult mothers ${ }^{3,14}$, were excluded. In addition, infants with no information on infant feeding practice and child growth, such as weight and height were excluded $(\mathrm{N}=63)$. Therefore, 3,601 mother and infant pairs were included in the analysis. Present study was approved by the National Ethical Committee, Ministry of Public Health in Thailand. All families were informed about study procedures and possible risks before signing the consent form.

\section{Exposure: Infant feeding practice variables}

Data of timing of complementary feeding introduction and types and duration of BF were collected by interviewer-administered questionnaires at 6, 12, 18 and 24 months. A similar set of questions was asked at each study period: 1) "Was the baby (still) breast-fed?"; "if no longer breast-fed, what was the age (months) at which BF stopped?" 2) "Was the baby (still) formula-fed?"; "if yes, when was the age (months) at which formulafeeding started (before 6 months or after 6 months)?".
Data on timing of CF introduction was recorded by using a food calendar. A colourful picture of food calendar was provided to mothers after giving birth to child and mothers were asked to stick the food stickers of individual food items corresponding to the month, when the food items were introduced to the child. The following set of questions was asked at 6 and 12 months: 1) "If after 6 or 12 months, specify the starting age (months)" and 2) some questions related to types of $\mathrm{CF}$ were asked aside from milk; "What age and what kind of food with preparing method was your child fed?". Breastfeeding duration ( $\leq 3,4-5$ and $\geq 6$ months), type of milk fed during the first 6 months (yes, no), continuous breastfeeding at 12 and 24 months of age (yes, no), and age of complementary food introduction $(<4$ and $\geq 4$ months $\mathrm{OR} \leq 2,3$ and $\geq 4$ months as appropriate) were created and used in the analysis.

Outcome: Weight gain and overweight variables Height and weight of children were measured by physician and specially trained research assistants. The measurements were taken according to recumbent length using a graduate board with a fixed headboard and movable footboard $(1 \mathrm{~m} / 0.1$ $\mathrm{cm}$ ), and recorded to the nearest $0.1 \mathrm{~cm}$. Age- and sex-specific body mass index (BMI) was calculated using the WHO child growth standard ${ }^{14}$. Children with a BMI-for-age $>2$ SDs from the WHO growth standard median were classified as overweight. In this study, weight gain $(\mathrm{kg})$ was defined as weight at birth minus body weight at the 24-month examination.

\section{Statistical analysis}

We examined approximate linear associations of covariates according to three doses of either starting age of $\mathrm{CF}$ or $\mathrm{BF}$ duration and the trend tests for linearity were conducted by treating the median value for each either $\mathrm{BF}$ or age of $\mathrm{CF}$ group as a continuous variable in the analyses. The associations of two exposure variables on the weight gain $(\mathrm{kg})$ and overweight risk after adjustment for selected confounders were investigated by multiple linear regression and logistic regression analysis, respectively. Statistical analyses were conducted with SAS for Windows (version 9.2).

\section{Results}

Subject characteristics are shown in Table 1 . Approximately $20 \%$ of mothers had college education or more and high BMI $\left(\geq 23 \mathrm{~kg} / \mathrm{m}^{2}\right)$, and lived in urban areas. Mean birth weight was $3.1 \mathrm{~kg}$ and $10.5 \%$ of infants weighed $2.5 \mathrm{~kg}$ or less at birth. Approximately 35\% infants were breastfed for less than 6 months. Mean age of introduction of any $\mathrm{CF}$ was 2.7 months. 
Table 1: General characteristics of study population

\begin{tabular}{|c|c|c|}
\hline Characteristic & Number $(\%)$ & Mean \pm SD \\
\hline \multicolumn{3}{|l|}{ Maternal characteristics } \\
\hline $\begin{array}{l}\text { Maternal age at delivery (years) } \\
20-34 \\
\geq 35\end{array}$ & $\begin{array}{c}3595 \\
3049 / 3580(85.2) \\
531 / 3580(14.8) \\
\end{array}$ & $28.2 \pm 5.69$ \\
\hline $\begin{array}{l}\text { Maternal education } \\
\leq \text { Primary school } \\
\text { High school } \\
\geq \text { College }\end{array}$ & $\begin{array}{l}1936 / 3568(54.3) \\
899 / 3568(25.2) \\
733 / 3568(20.5) \\
\end{array}$ & \\
\hline $\begin{array}{l}\text { Maternal pre-pregnancy } B M I \\
<18.5 \mathrm{~kg} / \mathrm{m}^{2} \\
18.5-22.9 \mathrm{~kg} / \mathrm{m}^{2} \\
\geq 23 \mathrm{~kg} / \mathrm{m}^{2}\end{array}$ & $\begin{array}{c}793 / 3590(22.1) \\
1966 / 3590(54.7) \\
831 / 3590(23.2)\end{array}$ & \\
\hline Study site (urban) & $666 / 3601(18.5)$ & \\
\hline Weight gain during pregnancy $(\mathrm{kg})$ & 2730 & $14.2 \pm 10.6$ \\
\hline Smoking during pregnancy (yes) & $62 / 3379(01.8)$ & \\
\hline Mode of delivery (normal) & $2582 / 3504(73.7)$ & \\
\hline Parity (number) & 3068 & $2.4 \pm 1.46$ \\
\hline Gestational age at birth (weeks) & 3329 & $38.8 \pm 1.85$ \\
\hline \multicolumn{3}{|l|}{ Infant characteristics } \\
\hline Gender (male) & $1807 / 3608(50.1)$ & \\
\hline $\begin{array}{l}\text { Birth weight }(\mathrm{kg}) \\
\text { Low birth weight }(<2500 \mathrm{~g})\end{array}$ & $\begin{array}{c}3468 \\
378 / 3608(10.5) \\
\end{array}$ & $3.1 \pm 0.44$ \\
\hline \multicolumn{3}{|l|}{ Infant feeding practice } \\
\hline $\begin{array}{l}\text { Breastfeeding duration (months) } \\
<4 \\
4-5 \\
6-11 \\
\geq 12 \\
\end{array}$ & $\begin{array}{l}1006 / 3572(28.2) \\
257 / 3572(07.2) \\
381 / 3572(10.7) \\
1928 / 3572(54.0) \\
\end{array}$ & \\
\hline $\begin{array}{l}\text { Type of milk at } 6 \text { months } \\
\text { Breast milk only } \\
\text { Formula milk only } \\
\text { Both breast milk and formula milk }\end{array}$ & $\begin{array}{l}1627 / 3536(46.0) \\
1285 / 3536(36.3) \\
624 / 3536(17.7) \\
\end{array}$ & \\
\hline $\begin{array}{l}\text { Continued breastfeeding at } 1 \text { year (yes) } \\
\text { Continued breastfeeding at } 2 \text { years (yes) }\end{array}$ & $\begin{array}{c}1854 \text { / } 3532(52.5) \\
674 / 3394(19.9) \\
\end{array}$ & \\
\hline Food introduction & & \\
\hline Age of food introduction ( $\geq 4$ months) & $911 / 3515(26.0)$ & \\
\hline $\begin{array}{l}\text { Food Introduction (months) } \\
\text { Any food } \\
\text { Eggs, liver, fish, chicken, and meats } \\
\text { Staple food including rice, cereals, and banana } \\
\text { Snack, soft drinks and dessert } \\
\text { Fruit juice } \\
\text { Fruits including orange and papaya } \\
\text { Vegetables }\end{array}$ & $\begin{array}{l}3515 \\
3507 \\
3567 \\
3435 \\
3117 \\
2863 \\
3499 \\
\end{array}$ & $\begin{array}{l}2.78 \pm 1.26 \\
4.73 \pm 1.52 \\
3.03 \pm 1.44 \\
6.91 \pm 2.27 \\
4.09 \pm 2.17 \\
5.68 \pm 2.45 \\
5.82 \pm 2.05\end{array}$ \\
\hline
\end{tabular}

Tables 2 and 3 show some potential confounding factors by using duration of $\mathrm{BF}$ and age of $\mathrm{CF}$ introduction. With increase of duration of BF (Table 2), maternal pre-pregnancy BMI, number of parity, and the proportion of normal delivery increased, but education level, weight gain during pregnancy, and living in urban decreased. In terms of type of food introduced, the age of animal source foods, fruit juice, and vegetable showed positively linear trend with increased BF duration, but sweetened foods, and fruits showed the reverse association. Characteristics of subjects according to age of CF introduction are shown in Table 3. Delayed introduction of complementary feeding had a significant positive association with higher maternal age at delivery, educational level, weight gain during pregnancy, non-smoking status, assisted or caesarean delivery and lower gestational age at birth of baby. 
Table 2: Maternal and infant characteristics and feeding practice according to duration of any breastfeeding

\begin{tabular}{|c|c|c|c|c|}
\hline \multirow[b]{2}{*}{ Characteristic } & \multicolumn{3}{|c|}{ Duration of any breastfeeding } & \multirow[b]{2}{*}{ p-value } \\
\hline & $<4$ months & 4-6 months & $\geq 6$ months & \\
\hline \multicolumn{5}{|l|}{ Maternal characteristics } \\
\hline Maternal age at delivery (Mean \pm SD years) & $28.2 \pm 5.9$ & $28.1 \pm 5.1$ & $28.1 \pm 5.7$ & 0.5705 \\
\hline Maternal education $(\% \geq$ High school $)$ & 69.9 & 71.6 & 32.7 & $<0.0001$ \\
\hline Maternal pre-pregnancy BMI $\left(\% \geq 23 \mathrm{~kg} / \mathrm{m}^{2}\right)$ & 18.7 & 19.1 & 25.5 & $<0.0001$ \\
\hline Region (\% Urban) & 39.7 & 32.7 & 7.1 & $<0.0001$ \\
\hline Weight gain during pregnancy (Mean \pm SD kg) & $16.2 \pm 0.39$ & $15.5 \pm 0.72$ & $13.3 \pm 0.25$ & $<0.0001$ \\
\hline Smoking during pregnancy (\% yes) & 2.0 & 2.1 & 1.6 & 0.3794 \\
\hline Mode of delivery ( $\%$ normal) & 61.0 & 64.3 & 79.9 & $<0.0001$ \\
\hline Parity (Mean \pm SD number) & $1.98 \pm 0.05$ & $2.01 \pm 0.09$ & $2.52 \pm 0.03$ & $<0.0001$ \\
\hline Gestational age (Mean \pm SD weeks) & $38.7 \pm 0.06$ & $38.7 \pm 0.12$ & $38.8 \pm 0.04$ & 0.1090 \\
\hline \multicolumn{5}{|l|}{ Infant characteristics } \\
\hline Gender (\% male) & 49.3 & 47.7 & 50.7 & 0.3309 \\
\hline Birth weight (Mean \pm SD kg) & $3.07 \pm 0.01$ & $3.13 \pm 0.03$ & $3.08 \pm 0.01$ & 0.9901 \\
\hline \multicolumn{5}{|l|}{ Infant feeding pattern } \\
\hline \multicolumn{5}{|l|}{ Food Introduction (Mean \pm SD months) } \\
\hline Any food & $2.73 \pm 0.04$ & $3.01 \pm 0.08$ & $2.78 \pm 0.03$ & 0.7453 \\
\hline Eggs, liver, fish, chicken, and meats & $4.48 \pm 0.05$ & $4.52 \pm 0.09$ & $4.86 \pm 0.03$ & $<0.0001$ \\
\hline Staple food including rice, cereals \& banana & $2.98 \pm 0.05$ & $3.22 \pm 0.09$ & $3.03 \pm 0.03$ & 0.9633 \\
\hline Snack, soft drinks and dessert & $7.21 \pm 0.07$ & $7.70 \pm 0.14$ & $6.70 \pm 0.05$ & $<0.0001$ \\
\hline Fruit juice & $3.98 \pm 0.07$ & $4.10 \pm 0.14$ & $4.16 \pm 0.05$ & 0.0438 \\
\hline Fruits including orange and papaya & $6.08 \pm 0.08$ & $5.82 \pm 0.16$ & $5.46 \pm 0.06$ & $<0.0001$ \\
\hline Vegetables & $5.38 \pm 0.07$ & $5.37 \pm 0.13$ & $6.07 \pm 0.04$ & $<0.0001$ \\
\hline
\end{tabular}

All values were adjusted for maternal age (years)

Table 3: Maternal and infant characteristics and feeding practice according to timing of any food introduced

\begin{tabular}{|c|c|c|c|c|}
\hline \multirow[t]{2}{*}{ Maternal and infant characteristics } & \multicolumn{3}{|c|}{ Age of starting any complementary feeding } & \multirow[t]{2}{*}{ p-value } \\
\hline & $\leq 2$ months & 3 months & $\geq 4$ months & \\
\hline \multicolumn{5}{|l|}{ Maternal characteristics } \\
\hline Maternal age at delivery (Mean \pm SD years) & $27.4 \pm 5.62$ & $28.7 \pm 5.70$ & $29.0 \pm 5.66$ & $<0.0001$ \\
\hline Maternal education $(\% \geq$ High school $)$ & 37.5 & 52.1 & 53.7 & $<0.0001$ \\
\hline Maternal pre-pregnancy BMI $\left(\% \geq 23 \mathrm{~kg} / \mathrm{m}^{2}\right)$ & 24.6 & 21.5 & 22.6 & 0.1698 \\
\hline Region (\% Urban) & 16.6 & 23.2 & 15.8 & 0.8473 \\
\hline Weight gain during pregnancy (Mean \pm SD kg) & $13.4 \pm 0.31$ & $14.7 \pm 0.36$ & $15.0 \pm 0.39$ & 0.0008 \\
\hline Smoking during pregnancy (\% yes) & 2.2 & $1-9$ & 0.8 & 0.0198 \\
\hline Mode of delivery ( $\%$ normal) & 78.6 & 71.1 & 68.2 & $<0.0001$ \\
\hline Parity (Mean \pm SD number) & $2.35 \pm 0.03$ & $2.26 \pm 0.04$ & $2.48 \pm 0.05$ & 0.0751 \\
\hline Gestational age (Mean \pm SD weeks) & $38.9 \pm 0.05$ & $38.8 \pm 0.06$ & $38.7 \pm 0.06$ & 0.0191 \\
\hline \multicolumn{5}{|l|}{ Infant characteristics } \\
\hline Gender $(\%$ male $)$ & 51.6 & 50.5 & 47.3 & 0.0493 \\
\hline Birth weight (Mean \pm SD kg) & $3.08 \pm 0.01$ & $3.08 \pm 0.01$ & $3.08 \pm 0.02$ & 0.9078 \\
\hline \multicolumn{5}{|l|}{ Infant feeding pattern } \\
\hline Breastfeeding duration ( $\% \geq 6$ months $)$ & 67.8 & 60.4 & 65.3 & 0.0750 \\
\hline Type of milk fed at 6 months & & & & \\
\hline Breast milk (\% yes) & 48.4 & 41.8 & 47.4 & 0.3096 \\
\hline Formula milk or both (\% yes) & 51.6 & 58.2 & 52.7 & \\
\hline Continued breastfeeding at 1 year (\% yes) & 56.6 & 48.0 & 51.4 & 0.0037 \\
\hline Continued breastfeeding at 2 years ( $\%$ yes) & 22.1 & 18.1 & 18.1 & 0.0120 \\
\hline
\end{tabular}

\section{All values were adjusted for maternal age (years)}

Table 4 shows the association between infant feeding practice and the risk of high weight gain and overweight after adjustment for the potential confounders. Longer BF for 12 months or more was inversely related to high weight gain $(\beta=-0.0101$, $\mathrm{p}<0.0001)$ and a risk of overweight [adjusted Odds Ratio $(\mathrm{aOR})=0.24,95 \%$ confidence interval $(\mathrm{CI})=$ 0.15-0.40) after adjustment for confounders. 
Starting age of any CF was not associated with either high weight gain or overweight risk. In light of specific types of foods, overweight risk decreased with increasing age (months) at introduction of animal source foods $(\mathrm{aOR}=0.78,95 \% \mathrm{CI}=0.67$ $0.91)$, vegetables $(\mathrm{aOR}=0.85,95 \% \mathrm{CI}=0.76-0.96)$, and fruit juices $(\mathrm{aOR}=0.92,95 \% \mathrm{CI}=0.83-1.01$ ), while higher weight gain had an inverse association with animal source foods $(\mathrm{p}=0.0004)$ and vegetables $(p<0.0001)$. The effect of animal source foods and vegetable did not change much even after additional adjustment of breastfeeding duration (data not shown). In a comparison of the effect of late $(\geq 4$ months) compared with early $(<4$ months $)$ introduction of $\mathrm{CF}$, the protective effects of their late introduction were observed.

Table 4: Association between feeding practice and risk of weight gain and overweight at 24 months of age

\begin{tabular}{|c|c|c|c|c|c|}
\hline \multirow[t]{2}{*}{ Label } & \multicolumn{3}{|c|}{ Weight gain 0 to 24 months } & \multicolumn{2}{|c|}{ Overweight } \\
\hline & $\beta$ & $S E$ & $p$-value & $a O R$ & $95 \% C I$ \\
\hline \multicolumn{6}{|l|}{ Breastfeeding $\dagger$} \\
\hline $\begin{array}{l}\text { Duration of any breastfeeding } \\
<6 \text { months } \\
6-11 \text { months } \\
12-24 \text { months }\end{array}$ & $\begin{array}{l}\text { Reference gp. } \\
-0.0018 \\
-0.0101\end{array}$ & $\begin{array}{l}0.0012 \\
0.0009\end{array}$ & $\begin{array}{c}0.1471 \\
<0.0001\end{array}$ & $\begin{array}{c}\text { Reference gp. } \\
0.71 \\
0.24\end{array}$ & $\begin{array}{l}(0.04,1.25) \\
(0.15,0.40)\end{array}$ \\
\hline $\begin{array}{l}\text { Continued breastfeeding at } 12 \text { months } \\
\text { No } \\
\text { Yes }\end{array}$ & $\begin{array}{c}\text { Reference gp. } \\
-0.9701\end{array}$ & 0.0777 & $<0.0001$ & $\begin{array}{c}\text { Reference gp. } \\
0.24\end{array}$ & $(0.14,0.40)$ \\
\hline $\begin{array}{l}\text { Continued breastfeeding at } 24 \text { months } \\
\text { No } \\
\text { Yes }\end{array}$ & $\begin{array}{c}\text { Reference gp. } \\
-0.8288 \\
\end{array}$ & 0.0904 & $<0.0001$ & $\begin{array}{c}\text { Reference gp. } \\
0.17 \\
\end{array}$ & $(0.06,0.47)$ \\
\hline \multicolumn{6}{|l|}{ Complementary foods $;$} \\
\hline $\begin{array}{l}\text { Timing of food Introduction ( } \geq 4 \text { months) } \\
\text { Any food } \\
\text { Animal source food } \\
\text { Staple food } \\
\text { Snack and soft drinks } \\
\text { Fruit juices } \\
\text { Fruits } \\
\text { Vegetables }\end{array}$ & $\begin{array}{l}-0.1332 \\
-0.2636 \\
-0.0562 \\
-0.0036 \\
-0.1686 \\
-0.1387 \\
-0.2591 \\
\end{array}$ & $\begin{array}{l}0.0800 \\
0.0971 \\
0.0745 \\
0.1872 \\
0.0758 \\
0.1070 \\
0.1426\end{array}$ & $\begin{array}{l}0.0960 \\
0.0067 \\
0.4503 \\
0.9847 \\
0.0262 \\
0.1951 \\
0.0693\end{array}$ & $\begin{array}{l}0.71 \\
0.59 \\
0.78 \\
1.40 \\
0.70 \\
0.66 \\
0.56\end{array}$ & $\begin{array}{l}(0.48,1.07) \\
(0.39,0.91) \\
(0.54,1.14) \\
(0.43,4.60) \\
(0.49,0.99) \\
(0.42,1.04) \\
(0.32,0.99)\end{array}$ \\
\hline $\begin{array}{l}\text { Timing of food Introduction (per } 1 \\
\text { month) } \\
\text { Any food } \\
\text { Animal source food } \\
\text { Staple food } \\
\text { Snack and soft drinks } \\
\text { Fruit juices } \\
\text { Fruits } \\
\text { Vegetables }\end{array}$ & $\begin{array}{l}-0.054 \\
-0.084 \\
-0.036 \\
0.0182 \\
-0.025 \\
-0.01 \\
-0.079\end{array}$ & $\begin{array}{c}0.0295 \\
0.0239 \\
0.0267 \\
0.0157 \\
0.017 \\
0.0169 \\
0.0184\end{array}$ & $\begin{array}{c}0.0667 \\
0.0004 \\
0.1745 \\
0.2440 \\
0.1488 \\
0.5448 \\
<0.0001\end{array}$ & $\begin{array}{l}0.92 \\
0.78 \\
0.95 \\
1.03 \\
0.92 \\
0.95 \\
0.85\end{array}$ & $\begin{array}{l}(0.78,1.07) \\
(0.67,0.91) \\
(0.82,1.11) \\
(0.96,1.12) \\
(0.83,1.01) \\
(0.88 .1 .04) \\
(0.76,0.96)\end{array}$ \\
\hline
\end{tabular}

B: Coefficients; SE: Standard Error; aOR: Adjusted Odds Ratio; CI: Confidence Interval, SE: Standard Error

$\dagger$ adjusted for maternal education level ( $\leq$ Primary school, $\geq$ High school), maternal pre-pregnancy BMI $(<18.5$, 18.5-22.9, $\geq 23$ ), urban (yes, no), weight gain during pregnancy (kg), mode of delivery (normal, c-sec), low birth weight (yes, no), parity (number)

$\$$ adjusted for maternal age (year), maternal education level ( $\leq$ Primary school, $\geq$ High school), weight gain during pregnancy $(\mathrm{kg})$, mode of delivery (normal, c-sec), smoking status during pregnancy, gestational age (weeks), infant's sex (male, female)

\section{Discussion}

Due to increasing prevalence of overweight in childhood in Thailand, identification of early determinants with emphasis on the first year of life is needed. Longer duration of $\mathrm{BF}$ for at least 12 months or more showed a strong reduction effect against the high weight gain and overweight risk in children at age of 24 months. Timing of any CF introduction was not associated but, late introduction of foods from animal source, fruit juices and vegetables after 4 months of life showed a small reduction. The results suggested that longer duration of $\mathrm{BF}$ and late introduction of animal source, fruit juices and vegetables prevent weight gain and reduce overweight risk.

The prevalence of overweight in children at 24 months was $4.3 \%$ when measured by weight for height $>2$ SDs from the WHO growth standard median and $5.8 \%$ measured by BMI-for-age $>2$ SDs. It is similar to that of national data from the Thailand Multiple Indicator Cluster Survey (MICS) of 2005$2006^{10}$, in which prevalence of overweight (weight for height $>2$ SDs from the WHO growth median) children aged 12-23 months was $6.2 \%$. Furthermore, 
Thailand has one of the lowest exclusive breast feeding $(\mathrm{EBF})$ rate in the world with early introduction of complementary foods ${ }^{16}$. The EBF rate at 6 months in the study was very low $(1.5 \%)$. From national data it was $5.4 \%$ among children $0-5$ months in $2006^{10}$ and $12 \%$ in $2012^{11}$ but when calculated by the end of 6 months it was below $1 \%$ in $2012^{11}$. More surprisingly, a proportion of babies never breastfed was $16 \%$ in $2009^{5,17}$. On the other hand, continuous $\mathrm{BF}$ rate at 12 months and 24 months in the study was $52.5 \%$ and $19.9 \%$, respectively. According to MICS 2012 ${ }^{11}$, the prevalence was $32.4 \%$ among infants $12-15$ months and $17.8 \%$ among infants $20-23$ months. With regard to starting age of complementary foods, mean age of starting complementary feeding was 2.78 months and approximately $74 \%$ of babies started before 4 months after birth in our study. The poor infant feeding practice may contribute to the increasing burden of overweight risk in Thai children.

This study showed that longer duration of BF is inversely related with weight gain and an overweight risk in early childhood, which is consistent with other studies ${ }^{6,18-22}$. However, the beneficial effect in adulthood is not consistent between studies. A recent meta-analysis review using five cohorts in low- and middle-income countries $^{23}$ reported that prolonged BF was associated with lower risk of hypertension, diabetes or overweight even in adults, while two cohort studies in $\mathrm{USA}^{5}$ and Denmark ${ }^{24}$ reported no relationships in adulthood ${ }^{5,24}$. Meanwhile, although the protective effect was reported in India $^{22}$ and China $^{20}$, studies in early childhood were mostly conducted in high income countries ${ }^{6,18,19,21}$. In highincome settings, highly educated mothers tend more to breastfeed exclusively than those less educated and their infants are less likely to become overweight or obesity. The patterned confounding of socioeconomic position (SEP) in breastfeeding in high-income countries may affect the causal inference ${ }^{5,25}$. The impact of residual confounding was examined by comparing cohorts from high income and low- or middle- income countries. Effect of longer duration of BF on BMI $\left(\mathrm{kg} / \mathrm{m}^{2}\right)$ was protective in ALSPAC study in UK, but not in Pelotas study in Brazil. Indeed, many studies showing their protective effect came from high income countries ${ }^{6,18,19,21}$. In our study, Thai infant breastfed longer were mostly from low socioeconomic status and live in rural area, while those likely to be overweight were mostly from higher SEP. Although we cannot control the residual confounding by SEP completely, careful selection of potential confounders related to pattern of breastfeeding or timing of $\mathrm{CF}$ introduction may minimize the effect.
Although stronger effect of late introduction of $\mathrm{CF}$ rather than $\mathrm{BF}$ either in early childhood ${ }^{4,6}$ or in adulthood $^{23,24}$ was reported in some studies, we found no protective effect of early introduction of any $\mathrm{CF}$, supported by the previous studies ${ }^{26,27}$. Generally, Thai mothers introduce $\mathrm{CF}$ at an early age $(2.78 \pm 1.26$ months $)$. A general type of $\mathrm{CF}$ given firstly to their children is thin porridge made of rice ${ }^{28}$ as shown in age of staple foods introduction in our study ( $3.03 \pm 1.44$ months $)$. As mothers tend to start complementary feeding at similar ages (months) regardless of weight status, it may result in no association in our study. Despite no significant association of the timing of any CF introduction in our study, we found a small reduction on the risk of overweight and weight gain of late introduction of animal source foods, fruit juices and vegetables. It was supported by a study of Schack-Nielsen L et al ${ }^{24}$ showing as introduction of vegetables, meat, and firm food increased one month, the risk of overweight at 42 years also increased and compared with children introduced before 4 months of age, those starting vegetables and spoon-feeding after 4 months of age showed lower risk of obesity after adjustment of confounders including breastfeeding duration in the model.

A possible explanation of the beneficial effect of longer $\mathrm{BF}$ and late introduction of $\mathrm{CF}$ is biological programming. For example, formula-fed infants have fat deposition and increased number of adipocytes through a greater insulin response compared to those breast-fed ${ }^{1,29}$. In addition, displacement of breast milk containing low protein by earlier introduction of $\mathrm{CF}$ including higher energy and protein ${ }^{30}$ may lead to high energy ${ }^{31}$ and protein intake ${ }^{32}$ in early life. It was supported by some previous studies ${ }^{4,31,32}$. In the ALSPAC birth cohort study in UK, higher intake at 4 months was related to higher weight gain and BMI at $1,2,3$, or 5 years of age but only found in formula- or mixedfed children at 4 months ${ }^{32}$. The result was also found in the Project Viva, a USA cohort study, showing a positive association between introduction of $\mathrm{CF}$ before 4 months and odds of obesity only in formula-fed infants ${ }^{4}$. In addition, higher protein intakes were associated with faster weight gain in an EU Childhood Obesity Trial study ${ }^{32}$.

Several limitations of the present study should be acknowledged. Residual confounding may distort the true relationship. To minimize the effect, we have included many confounding variables and adjusted for the potential confounders with consideration of the relation of breastfeeding or timing of complementary feeding. Secondly, we collected information on infant feeding from mothers' recall and it may result in recall bias. The prospective nature of the information presented 
decreased the likelihood of recall bias. Finally, misclassification of breastfeeding or timing of $\mathrm{CF}$ introduced can be an issue that should be taken into consideration. It is likely to be non-differential so that this may lead to the results towards the null.

\section{Conclusion}

Longer duration of breastfeeding for at least 12 months and late introduction of animal source foods, fruit juices and vegetables after 4 months reduce the risk of overweight and weight gain in children at 24 months of age in this Thai study population.

\section{Acknowledgements}

The authors thank the families who participated in this study. Special Thanks to Dr. Chanpen Chooprapawon, Assoc. Prof. Ladda Mo-Suwan and Assist. Prof. Uraiporn Chittchang for their contribution. The prospective cohort study of Thai Children (PCTC) was supported by the Thailand Research Fund, the Health System Research Institute, the Ministry of Public Health, DUMEX Science, ASEAN Institute for Health Development, Mahidol University, and the World Health Organization.

\section{References}

1. Harrington JW, Nguyen VQ, Paulson JF, Garland R, Pasquinelli L, Lewis D. Identifying the "tipping point" age for overweight pediatric patients. Clinical Pediatrics (Phila) 2010; 49(7):638-43. https://doi.org/10.1177/000992280935941 8

PMid: 20150210

2. Daniels SR, Arnett DK, Eckel RH, Gidding SS, Hayman LL, Kumanyika S, et al. Overweight in children and adolescents: pathophysiology, consequences, prevention, and treatment. Circulation 2005; 111(15): 1999-2012.

https://doi.org/10.1161/01.CIR.000016136 9.71722.10

PMid: 15837955

3. Butte NF, Wong WW, Hopkinson JM, Smith EO, Ellis KJ. Infant feeding mode affects early growth and body composition. Pediatrics 2000; 106(6):1355-66. https://doi.org/10.1542/peds.106.6.1355 PMid: 11099589

4. Huh SY, Rifas-Shiman SL, Taveras EM, Oken E, MW. Timing of solid food introduction and risk of obesity in preschool-aged children. Pediatrics 2011; 127(3):e544-551.

https://doi.org/10.1542/peds.2010-0740

PMid: 21300681 PMCid: PMC3065143

5. Michels KB, Willett WC, Graubard BI, Vaidya RL, Cantwell MM, Sansbury LB, et al. A longitudinal study of infant feeding and obesity throughout life course. International Journal of Obesity (Lond) 2007; 31(7):1078-85.

https://doi.org/10.1038/sj.ijo.0803622

PMid: 17452993

6. Baker JL, Michaelsen KF, Rasmussen KM, Sørensen TI, et al. Maternal pre-pregnant body mass index, duration of breastfeeding, and timing of complementary food introduction are associated with infant weight gain. American Journal of Clinical Nutrition 2004; 80(6):1579-88.

PMid: 15585772

7. Araújo CL, Victora CG, Hallal PC, Gigante DP. Breastfeeding and overweight in childhood: evidence from the Pelotas 1993 birth cohort study. International Journal of Obesity (Lond) 2006; 30(3):500-6.

https://doi.org/10.1038/sj.ijo.0803160

PMid: 16276362

8. Pitayatienanan P, Butchon R, Yothasamut J, Aekplakorn W, Teerawattananon Y, Suksomboon N, et al. Economic costs of obesity in Thailand: a retrospective cost-ofillness study. BMC Health Services Research 2014; 14:146.

https://doi.org/10.1186/1472-6963-14-146 PMid: 24690106 PMCid: PMC4109797

9. Aekplakorn W, Hogan MC, Chongsuvivatwong V, Tatsanavivat $\mathrm{P}$, Chariyalertsak S, Boonthum A, et al. Trends in obesity and associations with education and urban or rural residence in Thailand. Obesity (Silver Spring) 2007; 15(12):3113-21.

https://doi.org/10.1038/oby.2007.371

PMid: 18198322

10. Thailand National Statistical Office. Thailand Multiple Indicator Cluster Survey (MICS). In Bangkok, Thailand, National Statistical Office; 2006.

11. Thailand National Statistical Office. UNICEF, Ministry of Public Health, National Health Security Office, Thai 
Health Promotion Foundation, International Health Policy Programme, Thailand Multiple Indicator Cluster Survey (MICS). In Bangkok, Thailand, National Statistical Office; 2012.

12. Pawloski LR, Ruchiwit M, Markham SM. The growing burden of obesity in Thailand: a review of current trends and policies. Pediatric Nursing 2011; 37(5):256-61.

PMid: 22132571

13. Mongkolchati A, Thinkhamrop B, MoSuwan L, Chittchang U, Choprapawon C. Prevalence and incidence of child stunting from birth to two years of life in Thai children: based on the Prospective Cohort Study of Thai Children (PCTC). Journal of the Medical Association of Thailand 2010; 93(12): 1368-78.

PMid: 21344798

14. Isaranurug S, Mo-Suwan L, Choprapawon C. Differences in Socio-Economic Status, Service Utilization, and Pregnancy Outcomes between Teenage and Adult Mothers. Journal of the Medical Association of Thailand 2006; 89(2): 14551.

PMid: 16578999

15. World Health Organization (2016). WHO Child Growth Standards: Length/Heightfor-Age, Weight-for-Age, Weight-forLength, Weight-for-Height and Body Mass Index-for-Age Methods and development. In. Geneva, Switzerland: World Health Organization.

16. United Nations Children's Fund. (2010). Situation Analysis of children and women in Thailand 2011. In: Bangkok; 2011. National Statistical Office: 2009 Reproductive Health Survey.

17. National Statistical Office: 2009 Reproductive Health Survey. In Bangkok, Thailand, National Statistical Office; 2010

18. Kalies H, Heinrich J, Borte N, Schaaf B, von Berg A, von Kries R, et al. The effect of breastfeeding on weight gain in infants: results of a birth cohort study. European Journal of Medical Research 2005; 10(1):36-42.

PMid: 15737952

19. Moss BG, Yeaton WH. Early Childhood Healthy and Obese Weight Status.
Potentially Protective Benefits of Breastfeeding and Delaying Solid Foods. Maternal and Child Health Journal 2014; 18(5):1224-32. https://doi.org/10.1007/s10995-013-1357z

PMid: 24057991

20. Zhang J, Himes JH, Guo Y, Jiang J, Yang $\mathrm{L}, \mathrm{Lu} \mathrm{Q}$, et al. Birth weight, growth and feeding pattern in early infancy predict overweight/obesity status at two years of age: a birth cohort study of Chinese infants. PLoS One 2013; 8(6): e64542. https://doi.org/10.1371/journal.pone.0064 542

PMid: 23755127 PMCid: PMC3673988

21. Scholtens S, Brunekreef B, Smit HA, Gast GC, Hoekstra MO, de Jongste JC, et al. Do differences in childhood diet explain the reduced overweight risk in breast fed children? Obesity (Silver Spring) 2008; 16(11):2498-503.

https://doi.org/10.1038/oby.2008.403

PMid: 18756263

22. Caleyachetty A, Krishnaveni GV, Veena SR, Hill J, Karat SC, Fall CH, et al. Breastfeeding duration, age of starting solids, and high BMI risk and adiposity in Indian children. Maternal and Child Nutrition 2013; 9(2):199-216. https://doi.org/10.1111/j.17408709.2011.00341.x PMid: 21978208 PMCid: PMC3378477

23. Fall $\mathrm{CH}$, Borja JB, Osmond $\mathrm{C}$, Richter L, Bhargava SK, Martorell R, et al. Infantfeeding patterns and cardiovascular risk factors in young adulthood: data from five cohorts in low- and middle-income countries. International Journal of Epidemiology 2011; 40(1):47-62. https://doi.org/10.1093/ije/dyq155 PMid: 20852257 PMCid: PMC3043278

24. Schack-Nielsen L, Sorensen TIA, Mortensen EL, Michaelsen KF. Late introduction of complementary feeding, rather than duration of breastfeeding, may protect against adult overweight. American Journal of Clinical Nutrition 2010; 91(3):619-27.

https://doi.org/10.3945/ajen.2008.27078 PMid: 20032492 PMCid: PMC2824155

25. Brion MJ, Lawlor DA, Matijasevich A, Horta B, Anselmi L, Araújo CL, et al. What 
are the causal effects of breastfeeding on IQ, obesity and blood pressure? Evidence from comparing high-income with middleincome cohorts. International Journal of Epidemiology 2011; 40(3):670-80. https://doi.org/10.1093/ije/dyr020 PMid: 21349903 PMCid: PMC3147072

26. Burdette HL, Whitaker RC, Hall WC, Daniels SR. Breastfeeding, introduction of complementary foods, and adiposity at $5 \mathrm{y}$ of age. American Journal of Clinical Nutrition 2006; 83(3):550-58.

PMid: 16522900

27. Lin SL, Leung GM, Lam TH, Schooling CM. Timing of solid food introduction and obesity. Hong Kong's "children of 1997" birth cohort. Pediatrics 2013; 131(5):e1459-1467.

https://doi.org/10.1542/peds.2012-2643

PMid: 23569095

28. Winichagoon P. Thailand nutrition in transition situation and challenges of maternal and child nutrition. Asia Pacific Journal of Clinical Nutrition 2013; 22(1):6-15

PMid: 23353605

29. Lucas A, Sarson DL, Blackburn AM, Adrian TE, Aynsley-Green A, Bloom SR.
Breast vs bottle endocrine responses are different with formula feeding. Lancet $1980 ; 1 ; 1267-9$.

https://doi.org/10.1016/S01406736(80)91 731-6

30. Pearce J, Langley-Evans SC. The types of food introduced during complementary feeding and risk of childhood obesity: a systematic review. International Journal of Obesity 2013; 37:477-85.

https://doi.org/10.1038/ijo.2013.8

31. Ong KK, Emmett PM, Noble S, Ness A, Dunger DB, ALSPAC Study Team. Dietary energy intake at the age of 4 months predicts postnatal weight gain and childhood body mass index. Pediatrics 2006; 117(3): e503- e508.

https://doi.org/10.1542/peds.2005-1668

PMid: 16510629

32. Escribano J, Luque V, Ferre N, MendezRiera G, Koletzko B, Grote V, et al. Effect of protein intake and weight gain velocity on body fat mass at 6 months of age: the EU Childhood Obesity Programme. International Journal of Obesity (Lond) 2012; 36(4):548-53.

https://doi.org/10.1038/ijo.2011.276

PMid: 22310472 